\title{
Civil (and Uncivil) Society in Exile: North Korean 'Balloon Warriors' in South Korea
}

Edition 1, 2020

Dr Jay Song

DOI: 10.37839/MAR2652-550X1.5

There is no active and independent civil society in North Korea. When North Koreans leave North Korea and settle in other countries, however, they start learning new concepts of democratic citizenship and liberal capitalist values and form communities in interaction with other members of the society they reside in.

According to the South Korean Ministry of Unification, by the end of 2019, 33,523 North Koreans have settled in South Korea. The number is negligible compared to almost 50 million South Koreans and 20-25 million North Koreans who make up the total population on the peninsula.

It has been a socio-political experiment for South Koreans to live with fellow Koreans from a different system in the North.

Of particular interest are the 'balloon warriors' among other North Korean defectoractivists in South Korea, whose campaigns directly target North Korean citizens and challenge the Kim Jong Un regime in Pyongyang.

\section{Civil (and uncivil) society in exile}

I define civil society as groups of people who form mass organisations with a common public agenda other than individual profit-making that challenges the incumbent governments, policies, and practices. The exact ingredients of this sphere 
vary. For Georg Wilhelm Friedrich Hegel, for instance, even the bureaucracy and corporations were part of civil society as against the ethical state. The approach of Karl Marx locates civil society with a class lens, as against the universal citizenship in the political sphere. For Alexis de Tocqueville, civil society is a space of voluntary associations which can replace primordial community. In reality, members of civil society are hugely diverse and heterogeneous, including a plethora of different and often opposed agents.

There are two main problems in applying existing theories of civil society to North Korea. First, existing studies on civil society often include normative assumptions on liberal values, democratic governance. Keck and Sikkink's spiral model of norm diffusion and domestic change is notable in this regard. The common assumption is that a civil society exists within the country of concern where domestic actors can interact with international human rights organisations while pressing the government for policy changes. Unfortunately, this is not a case for North Korea as it has no active civil society, except in the form of groups in 'exile' in South Korea.

Second, not all of the movements North Korean defectors organise in South Korea are civil. In their work on post-Communist Europe, Petr Kopecký and Cas Mudde have highlighted the existence of 'uncivil society', which include 'organizations that use violence in order to achieve their goals, or groups with non-democratic or (rightwing) extremist ideas'. Uncivil society lacks civility, public mindedness, a sense of active citizenship and, most of all, support for liberal values, which imposes pluralism. Uncivil society is also against Robert Putnam's propositions of social capital, public trust, and reciprocity that would underpin the basis of liberal democracy in Western society. This is also not always the case for North Korean civil society in exile in South Korea. To avoid this 'normative trap' in existing literature on civil society, Neera Chandhoke suggests that we analyse actually existing civil and uncivil societies in context. I follow her advice for this study on North Korean civil (and uncivil) society in exile in South Korea.

Among those 33,247 North Korean defectors in South Korea, I chose to focus on 
North Korean 'balloon warriors' as they claim to represent the defector community in South Korea, directly target North Korean citizens by sending messages in leaflets via air-borne balloons, and lead an ultimate revolution to topple the Kim regime in North Korea. The exact number of these balloon warriors is unknown as it varies from one bus-load campaign to another at the borders between the two Koreas. This study analyses the balloon warriors' online and offline campaigns over the past decade and includes in-depth individual and focus group interview data from North Korean defectors in South Korea, conducted in July-August 2019.

\section{Why there is no civil society in North Korea}

There are no strong civil society actors that can push for market reforms and openings and even localised protests are rare. Balazs Szalontai and Changyong Choi provide an excellent analysis on why this is the case. They not only highlight potential groups that may challenge the Kim regime, including industrial workers, private entrepreneurs, and religious, ethnic, and regional groups, but also conclude that none of these groups have sufficient means to revolt against the government.

Among these groups, there have been small signs of resistance. Restrictions on private trade in 2008, for example, triggered protests among market vendors in Chongjin, North Hamgyong Province. The currency reform of December 2009 caused strong public discontent. Surveys of North Korean refugees indicate that following those anti-market measures, North Koreans held the state responsible for their hardship. If ever, Chongjin or Hamhung in the country's north-eastern region that were formerly industrial cities are more likely to become centres of opposition. Both cities underwent serious decline in the 1990s due to economic malfunctioning, external post-Cold war factors, and the regime's anti-market policies, which fuelled local resentment against the state. Several episodes indicate that socio-political tension and market unrest existed in Chongjin and Hamhung, including the 2008 protests of vendors and the riots after the 2009 currency reform. However, these events did not turn into popular rebellion as in the 1989 Romanian or 2011 Tunisian 
transitions.

The North Korean state has been responsive to any signs of rebellion. First, the leadership avoided taking extreme measures which could trigger protests. The discontent was not necessarily directed against the top leadership but contained at a local level. Even a state failure in the 1990s produced an adverse effect on the social cohesion and bargaining power of North Korean workers, instead of facilitating resistance. Second, the authorities tolerated market activities. Private entrepreneurship, although limited, alleviated state-society tension. Even if the regime's anti-market measures triggered occasional unrest, the private sector lacked sufficient bargaining power to effectively defy the state. North Korean entrepreneurs have no established independent business association to collectively bargain with and sometime against the state. Instead, they turn to lower-level state officials to operate successfully via deeply embedded bribery in the system. Third, if any resistant groups were found, state control was exerted forcefully. These groups were either socially marginalised or eliminated by forced migration or internal displacement. In a weak society like North Korea, individuals choose to pursue inconspicuous noncompliance or seek tacit cooperation and protection by lower-level officials, which is a far more effective strategy than popular rebellion, which is likely to fail.

\section{The 'balloon warriors': civil (and uncivil) society in exile}

In South Korea, under the two conservative governments (2008-2017), anticommunist and anti-Kim North Korean defector groups proliferated. According to a South Korean newspaper (but denied by the governments), the conservative Lee Myung-bak and Park Geun-hye administrations provided North Korean human rights groups a total of KRW 400 million, equivalent to AU506,000, between 2012 and 2014, which attracted significant attention from domestic and Western, calling them 


\section{'balloon warriors'.}

These largely North Korea-born activists had few ties to other South Korean grassroot organisations. Rather than being a part of an active, pro-democratic civil society in South Korea, they create a 'civil society in exile' in isolation from other civil society actors in South Korea, including other North Korean defectors who do not engage in this sort of subversive militant activism against the North Korean regime.

Since the early 2000s, groups were formed to send leaflets and USBs across the demilitarized zone (DMZ) from the southern side to the North. They include the Unification Media Group, North Korea Intellectual Solidarity, North Korea Strategy Center, No Chain, FNKR, Fighters for Free North Korea, Now Action Unity Human Rights, small churches that support individual initiatives, and other private groups. Moreover, there were approximately 50 balloon warriors in South Korea in 2016, many of whom were defectors. Smuggled contents include South Korean news, literature, music, soap operas, entertainment, interviews with defectors, and stories about everyday life outside of North Korea.

Supporters of balloon warriors believe North Koreans' repeat exposure to foreign information can erode citizens' trust in the North Korean leadership and may have a lasting impact by weakening the regime. This wishful thinking continues with support for subversive balloon leaflet campaigns, carried out by North Korean defector organisations in South Korea and their financial supporters.

There is no evidence that sending information to North Korea increased attitudinal shifts that can eventually bring about collective action against the regime in North Korea. Even among South Korean conservatives, South Korean national assemblyman, Ha Tae Kyung, claims that the balloons never reached the North but rather ended up being rubbish in South Korean coastlines for which the balloon warriors had to pay fines for environmental protection.

The kind of information going into North Korea is important in assessing the actions 
of the "balloon warriors". The subject matter of the leaflets is varied but aims to tarnish the regime's legitimacy or incite revolt against it. Three examples are:

- Images of the 'three Kims' in Pyongyang's leadership (Kim Il-sung. Kim Jong-il and Kim Jong-un), calling the regime a 'chubby republic' (ttongtteng'yi konghwaguk); naming the family's health conditions (stroke, obesity, and diabetes) as diseases of 'eating too well'; and disclosing Kim Jong Un as a child born out of wedlock

- A leaflet which claims North Korea's First Lady Lee Sol Ju has appeared in sex videos, suggests she was a porn star, and calls for her execution by shooting

- A leaflet which displays graphic images of the last days of dictators such as Romania's Nicolae Ceaușescu, Iraq's Saddam Hussein, and Libya's Muammar Gaddafi

One of the pioneering balloon warriors, Lee Min Bok, explained in an YouTube interview in 2013 that crude North Korean style language in the leaflets is used to directly target North Koreans. The distressing images of former dictators were a later invention by other more militant defectors and support organisations. Both the tactics and contents of balloon warriors are against peaceful and democratic principles and civility. The often crude and propagandistic dimension of the images and text illustrates a kind of North Korean society in exile in South Korea that is not civil or civilised in many South Koreans' eyes and isolates 'balloon warriors' from South Korean civil society.

The ceased propaganda broadcasting by the South Korean military was, in fact, a result of inter-Korean agreements in which both Koreas agreed to lessen political and military tensions between the two around border areas to create peaceful environments on the peninsula. Balloon warriors' subversive acts, therefore, breached not just North Korea's sovereignty and territorial integrity, but also bilateral agreements between the two Koreas. Furthermore, their militant form of campaigning put local South Koreans in danger. Those who lived around the border 
areas in Paju feared that the North reacted violently to the balloon leaflet campaigns set by defectors and protested against any further balloon campaigns, which led to violent clashes between North Korean balloon warriors and local South Koreans amidst police presence in 2014.

In a focus group discussion in Seoul in 2019, four North Korean human rights activists and volunteers shared their views about and motivations to join civic movements. To protect their identity, I use pseudonyms. First of all, they all expressed how disappointed they were that South Koreans seemed to be "indifferent" towards unification and North Korean matters.

John, a male professional activist in his 40s who has joined the balloon campaigns twice in the past, believes that 'sending information is key to change North Korean society and it does not matter how you do it'. Adam, a male volunteer in his 30s who has lived in South Korea for 12 years, also has a strong conviction that Kim Jong Un is evil, and the regime must be destroyed. He would join any protests against the Kim regime. Adam also adds that the previous governments were 'better' in financially supporting the balloon campaigns which he joined. During the Park Geunhye administration (2013-2016), North Korean defectors were indeed paid KRW20,000 (approximately USD18) per day to attend pro-Park rallies, which were not necessarily anti-Kim.

Joy and Christine are female college students in their mid-20s and volunteer for one of the North Korean human rights organisations in Seoul. They have lived in South Korea for six and five years, respectively. Joy was referred to the organisation by one of the missionaries from her church as she was looking for an internship. Christine is Joy's friend from the same church who followed Joy for the purposes of building social networks and learning English and other IT skills through the organisation. Both appreciated the opportunity to meet people including foreigners who they could practice English with for free as private English lessons in South Korea were costly. They do not particularly support the balloon campaigns as they were merely 'shows' to attract funding without any real impact on people in North Korea. They 
also do not like the language used in the leaflets as it is 'too North Korean'.

Getting a decent job in South Korea is challenging for North Korea-born college graduates, Joy and Christine say, as they lack English language and IT skills. Churches and these NGOs help them acquire those skills. In fact, all of the four participants I interviewed were Christians. Evangelism is a strong backbone of balloon campaigns. Lee Min-bok, for example, used to be a scientist at the Institute of Agricultural Sciences in Pyongyang before defecting to South Korea in 1995 and becoming a missionary. He launched the balloon campaigns in 2003 as a member of the Federation of Christian Defectors and has reportedly scattered around four hundred million leaflets over the DMZ. Lee believes that North Koreans are 'hopeless, starving, degenerating, and, as a result, undemocratic' because they do not listen to the Christian gospel.

\section{Conclusion}

On the one hand, balloon campaigns represent the 'ideological continuity of anticommunist, right-wing politics with a militant form of transnational secular evangelism', constructed by South Korean political environments of the time. On the other, balloon warriors and North Korean human rights activists in general were adapting to the environments and interacting with those who had material and ideational resources to provide for them.

North Korean defectors' internalisation of liberal values and anti-communism is natural, given the political and religious surroundings they were exposed to when they were brought into South Korean society. Back in North Korea, they had never learned or practiced liberal concepts such as democracy, liberty, human rights, civil society, public trust, political participation, and pluralism in a capitalist state. Binary thinking of good vs. evil from Christianity, victim vs. perpetrator from human rights, and freedom-fighter vs. dictator from anti-communism are spoon-fed to them in the liberal Christian rescue package. This mental epistemology is not vastly different 
from the North Korean monolithic state ideology, which employs equally binary thinking: between our nation under the great leader versus American imperialists and their South Korean puppets. All they have to do is to flip the sides in a different ontological mental map. North Korean defectors transplant a North Korean society in South Korea, carrying on their civil and uncivil strategies to fight against their enemy - their former leaders, the Kim family in the North. Their new patrons in the liberal capitalist South are not permanently secured. There are competing ideas and civic organisations in their newly adopted society in South Korea. It is a learning process for North Koreans in South Korea. It is also a test for South Koreans to accommodate civil and uncivil North Korean societies as part of a broader peace and reconciliation process with their fellow Koreans from - and hopefully in - North Korea eventually.

The author would like to thank Professor Akihiro Ogawa for giving her an opportunity

to present the current work for the international conference on Civil Society and Authoritarianism in Asia, Professor Roland Bleiker for his generous and thoughtful comments on an earlier version of this piece, and the anonymous referee who accepted the manuscript.

Main image: Activists release huge balloons carrying anti-North Korea leaflets at Imjingak peace park in Paju near the heavily fortified frontier on April 15, 2011. Credit: JUNG YEON-JE/AFP via Getty Images) 